\title{
ARISTOTELÉS O POVAZE A POHYBU NEBESKÉ SFÉRY II $O$ nebi a problém nehybného hybatele
}

\section{Karel Thein}

První dvě knihy Aristotelova pojednání $O$ nebi postulují dokonalý kruhový pohyb jako pohyb nebeské sféry; z vlastností tohoto pohybu je pak odvozeno stejně dokonalé tzv. první těleso, které tento pohyb věčně uskutečňuje a jemuž je na základě jeho věčné skutečnosti a vnitřní oživenosti propůjčen božský status. Řada pasáží v první i druhé knize popisuje první těleso jako svého druhu dokonalou, vnitřně oživenou látku, místně oddělenou od zbytku fyzikálního světa. Takto chápaná fyzikální dokonalost je teoretickou inovací bez jasného předznamenání u starších autorů - a není proto překvapení, že Aristotelovo pojetí prvního tělesa budí značné rozpaky i v rámci peripatetické školy, od aporií v Theofrastově Metafyzice (6-9,5a14-b18; 11-12,6a5-14) až po jasné odmítnutí v Xenarchově spisu Proti páté podstatě. ${ }^{1}$ Až pozdější komentátorská tradice, počínaje Alexandrem z Afrodisiady, bude vůči Aristotelově kosmologii vstřícnější, většinou však za předpokladu jejího podřízení širšímu metafyzickému schématu, v němž je i pohyb nebeské sféry závislý na věčné skutečnosti prvního nehybného hybatele. Následující řádky se nezabývají touto dodnes vlivnou tradicí; jejich skromnějším cílem je zjistit, jak dalece je spis $O$ nebi otevřen pojmové syntéze nelátkového hybatele a výměru „božského tělesa“ skrze činnost, kterou je sám věčný kruhový pohyb. První část této studie nabídla rekonstrukci postupu, jenž učinil z prvního tělesa plně autonomní, byt' ryze fyzikální bytost, ,první z tělesných podstat", jež má být plně ve shodě s obecně lidským přesvědčením o existenci bohů (De caelo, II,3,270b1-11). ${ }^{2}$ Druhá část nabízí

1 K Theofrastovi (včetně některých tvrzení z jeho De igne) viz R. W. Sharples, Theophrastus on the Heavens, in: J. Wiesner (vyd.), Aristoteles: Werk und Wirkung, I, Berlin 1985, str. 577-593. Xenarchovo čtení shrnuje A. Falcon, Aristotelianism in the First Century BCE: Xenarchus of Seleucia, Cambridge 2012, str. 25-32. Postoj Stratóna z Lampsaku je též odmítavý, naneštěstí však velmi špatně dochovaný.

2 K. Thein, Aristotelés o povaze a pohybu nebeské sféry, I, Nebe jako tělesná podstata, in: Reflexe, 55, 2018, str. 5-22. 
výklad tří různých pasáží, v nichž byly spatřovány odkazy na motiv nelátkového hybatele, jenž by překročil fyzikální obzor zbytku pojednání a umožnil jeho propojení s Fyzikou VIII a Metafyzikou XII.

První a třetí z těchto pasáží (De caelo, I,9,279a11-b3 a II,12,292a14b25) představují bohatě komentované a značně nejasné texty, jejichž součástí je motiv „zcela prvního a nejvyššího božstva“ (279a32-33) či „nejbožštějšího počátku“ (292b22). Podrobný výklad však ukáže, že oba texty jsou vzhledem k motivu nehybného hybatele zcela neutrální a nijak nenaznačují, čím presně by snad tento motiv přispěl k rotaci prvního tělesa, které je původně a samostatně pohyblivé bez možných změn svého pohybu. Otázku takového přispění však navozuje druhá pasáž (De caelo, II,6,288a27-b7), jež jako jediná výslovně zmiňuje „,netělesného hybatele“. Celková argumentace tohoto textu se ovšem drží na čistě fyzikální rovině a roli nehybného hybatele stěží načrtává; navíc tak činí způsobem, jenž se liší od Fyziky VIII stejně jako Metafyziky XII. Vzhledem k míre, v níž se tři uvedené pasáže vzájemně liší, je jejich postupný komentář jistě nejjednodušší a nejbezpečnější formou následujícího výkladu. Celkovější úvahu naopak nabídne Závěr obou studií, jenž shrne možné Aristotelovy důvody pro vypracování zvláštního pojmu prvního tělesa a stručně je porovná s důvody pro zavedení prvního nehybného hybatele v jiných textech. Oproti běžnějším snahám o syntézu těchto důvodů se Závěr pokusí naznačit, čím je odlišnost obou případů filosoficky plodná.

\section{O nebi $\mathrm{I}, 9,279 \mathrm{a} 11-\mathrm{b} 3$}

První z textů uváděných na oporu mínění, že pojednání $O$ nebi mlčky předpokládá prvního netělesného hybatele, je tematicky nejrozmanitější a nejsložitější co do vzájemné artikulace svých postupných argumentačních kroků. Následující citace celé pasáže dělí tento postup do čtyř částí, jejichž vztah snad pomůže osvětlit místo této pasáže v celém pojednání: ${ }^{3}$

(1) „Zároveň [tj. spolu s tím, že tento svět je jediný a úplný] je jasné,

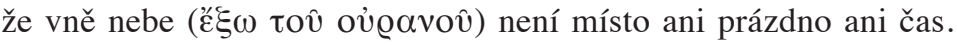
V každém místě totiž může být těleso; a prázdnem nazývají to, v čem těleso není, ale může být; čas je číslem pohybu, přičemž pohyb není

3 Česky citované pasáže spisu $O$ nebi se opírají o často výrazně pozměněný překlad M. Okála in: Aristotelés, O nebi-O vzniku a zániku, Bratislava 1985. V př́ípadě jiných spisů cituji namnoze upravené překlady A. Kř́̌že (jsou-li k dispozici). 


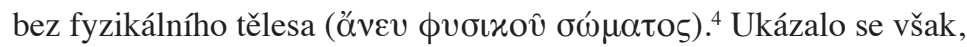
že vně světa není ani nemůže být žádné těleso. Je tedy zřejmé, že vně [světa] není místo ani prázdno ani čas.“ (I,9,279a11-18)

(2) „Proto věci tam ( $\tau \dot{\alpha} x \varepsilon \hat{)})$ nejsou přirozeně v místě ani časem nestárnou, ani žádná z věcí nad krajním oběhem (vंjè

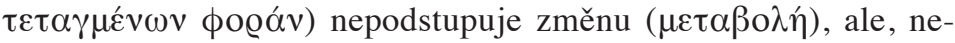

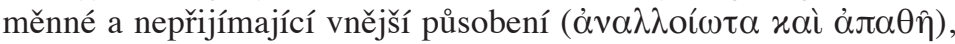

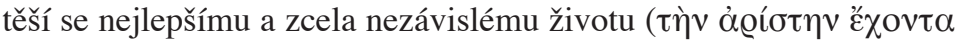

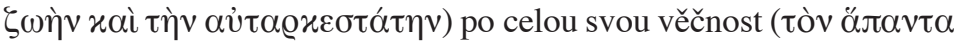
$\alpha i \hat{\omega} v \alpha)$. Tohoto slova, $\alpha i \omega$ v, užívali staří božsky. Nebot' mez ohrani-

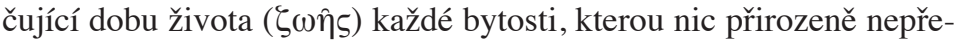
sahuje, se nazývá trvání života ( $\alpha i \omega ́ v)$ )“ (I,9,279a18-25)

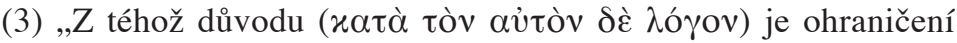
( $\tau \hat{\varepsilon} \lambda$ os) celého nebe a ohraničení celého času a [jeho] neomezenosti

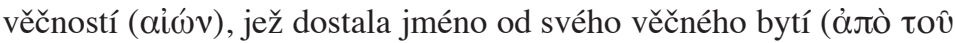

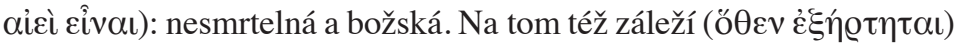

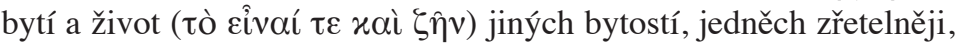
jiných nejasně.“ (I,9,279a25-30)

(4) „A vskutku, ve veřejně šîrených filosofických úvahách o božstvech

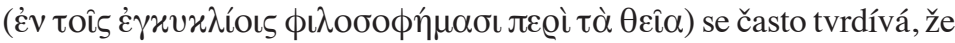

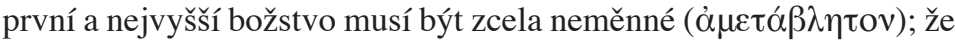
je tomu tak, svědčí ve prospěch toho, co jsme řekli. Není totiž nic moc-

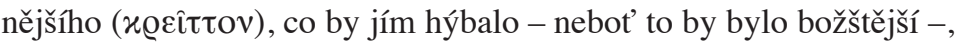

4 Celé souvětí je nejstručnějším shrnutím závěrů o místu, prázdnu a času z Phys. IV, včetně odmítnutí existence prázdna na základě vzájemné implikace tělesa a místa. Věta „prázdnem označují to, v čem těleso není, ale může být“ míŕí zjevně na stoupence prázdna, jejichž názory Phys. IV vyvrací. Korelátem těchto úvah je odmítnutí existence nekonečného tělesa rovněž ve Phys. IV a podrobněji v De caelo, I,5-7.

5 Okál překládá poslední větu této argumentace odlišně: „Preto tiež aj pre ostatné bytosti, pre jedny názornejšie, pre druhé menej jasne, je spojené bytie a život.“

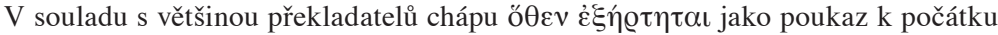
kauzálního řetězce: bytí a život se předávají od pohybu nejzazší nebeské sféry směrem dolů. Pro obdobné užití slovesa éç $\alpha \varrho \tau \alpha ́ \omega$ viz Platón, Ion, 536a3-6, o inspiraci vycházející ze svého počátku podobně jako magnetická síla z „héraklejského kame-

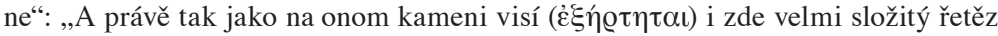
sborových zpěváků, sbormistrů a podsbormistrů, zavěšených ze strany na článcích, držících se Múzy.“ 
ani nemá žádnou vadu ani mu neschází žádná z jeho skvělých vlastností. Je tedy patřičné, že se pohybuje neustávajícím pohybem (xoì

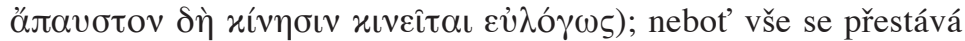
pohybovat, když dosáhne svého vlastního místa, ovšem v případě tělesa pohybujícího se v kruhu je místo, odkud pohyb začal, stejné jako

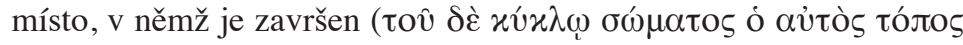

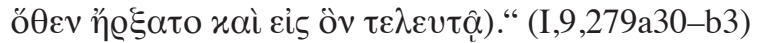

Pokusme se nyní o výklad všech čtyř částí a různých úloh, které jim v celkové argumentaci náleží. ${ }^{6}$ Část (1) je s ohledem na naše téma prostě přípravná a v nejvyšší mîre obecná: lze-li snad uvažovat o něčem za hranicí tohoto a jediného světa, tedy za hranicí rotujícího prvního těla, jistě

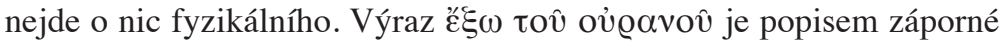
vlastnosti, kterou je absence jakéhokoli umístění, a tím též místního pohybu. Část (2) rozvíjí hypotetickou úvahu novým směrem, jehož smysl je již od antiky nejspornějším prvkem tohoto textu: případným „,věcem tam“ (což je neutrální překlad stejně neurčitého a jinde neužitého výra-

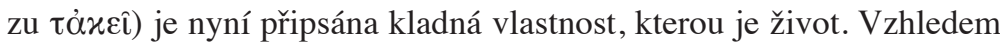
k absenci veškeré změny (nebot' mimo fyzikální obor prostě žádná nastat nemůže) jde navíc o život „,nejlepši““, jinými slovy na ničem nezávislý

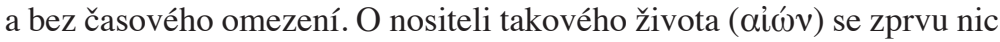
dalšího nedozvíme, dokonce ani to, že je božskou bytostí, nebot' Aristotelés pouze konstatuje, že staří myslitelé užívali výrazu aíóv „božsky“. Tato souhlasná poznámka však připravuje přenos ze způsobu řeči na to, o čem se mluví. Tomuto předmětu se pak věnuje část (3), jež propojuje místní ohraničenost světa na straně jedné s jeho věčným, vnitřně oživeným trváním na straně druhé. Tato věčnost označená za věčně realizo-

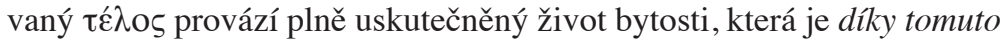
životu bytostí „,nesmrtelnou a božskou“. Jako taková je pak tato bytost příčinou, na níž závisí „bytí a život“ řady dalších bytostí.

Následující část argumentu, tedy část (4), nabídne výslovný popis této božské bytosti jako samostatně pohyblivé, čímž budou z možných kandidátů na tento status vyloučeny ,věci tam“, jejichž nestárnoucí neměnnost

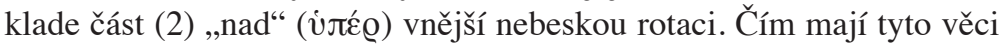
být a v čem by měl spočívat jejich život, je předmětem sporů mezi antickými stejně jako moderními komentátory a žádná z navržených možností

6 S výjimkou části (2) a výrazu đỏxeî ponechám stranou starší výklady celé pasáže, jejichž přehled by tuto studii neúnosně prodloužil. Pro podrobný výklad textu včetně jeho starších interpretací viz zejména F. Baghdassarian, Aristote, De Caelo, I, 9: l'identité des „êtres de là-bas“, in: Philosophie antique, 11, 2011, str. 175-203. 
nenabízí jasné řešení. Že nejde o ryze abstraktní předměty myšlení, je patrné z jejich oživenosti, přičemž text na druhé straně neříká ani to, že by př́slušný život pozůstával z činnosti myšlení, podobně jako je tomu u prvního nehybného hybatele z Metafyziky XII. Už Alexandr z Afrodisiady tvrdí, že citovaný text se může vztahovat bud’ k prvnímu hybateli, nebo ke sfére stálic (viz Simplikios, In De caelo, 287,19-23). S ohledem na použité množné číslo se Alexandr zřejmě kloní k nebeským sférám a jejich zcela přirozeným hybatelům, což je však čtení těžko slučitelné s následnou projekcí těchto věcí mimo každé místo čili (nutně metaforicky) „nad“ vnější mez nebeské sféry. ${ }^{7}$ Navíc platí, že i kdybychom tvrdili, že netělesní hybatelé nebeských sfér (o nichž spis $O$ nebi mlčí) jsou v místě jen akcidentálně, stěží lze rozvázat jejich vždy jedinečnou vazbu na tu či onu místně určenou sféru: tato vazba brání tomu, abychom je označili za společně existující za krajní mezí nebe.

Sám Simplikios se proto domnívá, že „věci tam“ je třeba chápat jako platónské předměty rozumu (In De caelo, 290,25-28). Toto tvrzení je sotva hajitelné z hlediska Aristotelovy vlastní nauky, může nám však napovědět, $v$ jakém smyslu zde Aristotelés opravdu naráží na platónsky chápané předměty rozumu, které nejsou součástí fyzikální osnovy

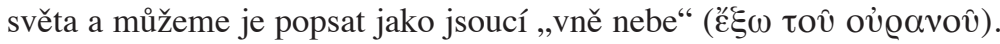
Tento výraz je vypůjčen z dialogu Faidros 247c2-3, kde Platón zároveň

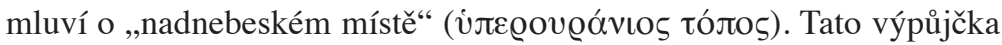
naznačuje, že stejně jako část (1) odmítá, co nejmenovaní „oni“ ř́kají o prázdnu, také část (2) se částečně vztahuje ke starším názorům: v daném př́ípadě k nauce, jejíž motivace je na rozdíl od obhajoby prázdna filosoficky chvályhodná, avšak chybně naplněná. Tento postup se pak vztahuje i na následný poukaz na „božské“ užití slova aî́vv: do textu zde, nikoli poprvé, vstupuje odkaz na starší nauku či rozšriřené mínění, jež potvrzují správnost naší cesty, ale neobsahují výslednou pravdu, k níž nás dovede až další argumentační posun.

Na podporu tohoto čtení lze připomenout i prostý fakt, že výraz ,věci tam“ ( xikální armatury Aristotelovy kritiky idejí: v Metafyzice I,9,991a1 je jasným označením oboru idejí v kontrastu s tím, co je „zde“. Je tedy možné, že Simplikiova perspektiva je nakonec věrnější než jiná čtení

7 Moderním obhájcem tohoto čtení je P. Moraux, Aristote, Du ciel, Paris 1965, str. xliv a pozn. 5 (s odkazy na starší stoupence této interpretace). Pro stručnou a jasnou kritiku viz L. Tarán, Paul Moraux: Aristote, Du ciel, in: Gnomon, 46, 1974, str. 129. Srv. také H. Cherniss, Aristotle's Criticism of Plato and the Academy, Baltimore 1944, str. 588. 
východisku (byt' ne záměru) části (2); odtud též její ozvěny u některých moderních čtenářron, včetně Zellera, Rosse či Solmsena. ${ }^{8}$ Dủležité je přitom též zdůraznit, že zmínka o „věcech tam“ nevede ani k náznaku jejich kauzálního vztahu k pohybu nebe ani jiným dějům v rámci světa, což je zcela v souladu s aristotelskou kritikou platonismu. Kauzální motiv se v celé argumentaci objevuje až v samém závěru části (3), ve větě „,na

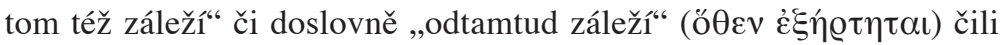
„odtamtud vychází" - zde se celá úvaha konečně obrací k počátku, jehož vliv je promítán do fyzikálního světa. Otázka tak zní, zda nám následná argumentace umožňuje tento počátek jednoznačně určit.

V této souvislosti je nejprve třeba připomenout, že již přechod od části (2) k části (3) nás vrací do souvislosti fyzikálního světa. Formulace „z téhož důvodu“ ( odkazuje na celou předešlou argumentaci a netýká se tedy toho, co by snad mohlo být vně nebeské sféry, nýbrž jejího vlastního ohraničení (srv.

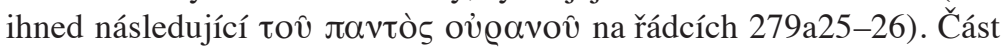
(4) rozvíjí stejné hledisko a to, na čem záleží bytí a život řady dalších bytostí, popíše jednoznačně jako kruhový pohyb nebeské sféry. První dvě věty části (4) jsou novou připomínkou sdílených či široce diskutovaných názorů o bozích a jsou natolik obecné, že se jistě hodí na jakékoli božstvo splňující nárok věčného života a neměnnosti. ${ }^{9}$ Aplikace tohoto základního mínění na samu „naši““ nauku je již výrazně užší a jasná: s oporou v tvrzení, že božstvu nic nevládne, nebot' nic není silnější (oǔt

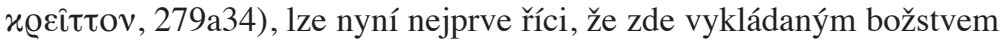

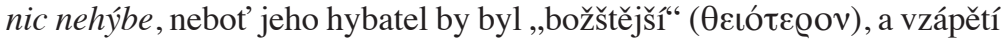
dodat, že se tedy ,pohybuje neustávajícím pohybem“ (279b1). Až tento dodatek jasně ukazuje, že zde pojednávané božstvo není první nehybný hybatel. Dodatečným potvrzením je pak návrat k propojení tělesné povahy daného božstva se zvláštní povahou kruhového pohybu: díky této povaze se lze zároveň hýbat a být v cíli tohoto pohybu, nebot' začátek a cíl zde spadají vjedno (279b1-3).

Část (4) tak dovádí citovanou pasáž k obecnějšímu a vzápětí konkrétnímu závěru. Na obecnější rovině se potvrzuje, že Aristotelés nečiní jasné terminologické rozlišení mezi „tím, co je božské“ a „bohem“,

8 Pro odkazy na jejich i další čtení viz souhrnně Moraux, Du ciel, str. xliv, pozn. 5.

9 Podle Simplikia zde Aristotelés naráží na svůj nyní ztracený exoterický spis

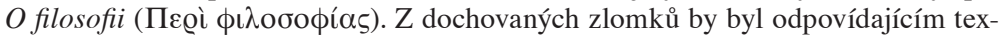
tem zlomek 16, in: W. D. Ross (vyd.), Aristotelis fragmenta selecta, Oxford 1955, str. 84 n., dochovaný právě díky Simplikiovu komentáři naší pasáže (viz In De caelo, $288,28-289,15)$. 
přičemž bůh - neměnná, věčně živá bytost - může být netělesný i tělesný, a to natolik, nakolik mu nic silnějšího nevládne. Na rovině přímo spjaté s tématem spisu $O$ nebi je pak řeč o božstvu tělesném, jehož věčná rotace je počátkem veškeré změny, z níž povstává bytí a život bytostí smíšených ze čtyř proměnlivých jednoduchých těles. Motiv kauzálního vlivu nebeské sféry na sublunární vznik a zánik je přitom dobře doložen ve spisu $O$ vzniku a zániku, II,10, kde je na pohyb nebe navázána vzájemná přeměna čtyř sublunárních jednoduchých těles stejně jako procesy vzniku a zániku živých bytostí kolem nás. Mechanika tohoto vlivu je v každém z těchto př́ípadů jiná a její př́edpoklady zde nemůžeme vykládat, obě vysvětlení jsou však jasně slučitelná s naším textem a potvrzují, že Aristotelés popisuje vznik a zánik v souvislosti dějů uvnitř fyzikálního kosmu. ${ }^{10}$ Netělesnými faktory, které v řadě jeho spisů do procesu vznikání a zanikání výslovně vstupují, jsou pouze vlastní formy jednotlivých druhů živých bytostí, jejich formálně i účelně působící duše.

Obecný výměr božstva je tedy v citované pasáži konkretizován skrze dokonalý pohyb a těleso, které ho vykonává, k čemuž je připojeno i potvrzení jeho svrchovaného vlivu na děje ve světě kolem nás. Toto zúžení je jistě dáno tématem prvních dvou knih spisu $O$ nebi. Oproti jiným pasážím však jde o text nejhůře slučitelný s případným mlčky předpokládaným působením prvního nehybného hybatele: řádky 279a34-279b1 přímo vylučují hybatele, jenž by byl „silnějšíi”, a tím „,božštější“. Odtud rozpaky čtenářu počínaje Simplikiem, jenž věnuje dlouhý závěr svého komentáře kapitoly I,9 snaze o syntézu jejích tvrzení s pasážemi z jiných textů, včetně Fyziky VIII, a to na základě předpokladu, že „,nebe se pohybuje v kruhu obráceno k rozumu a toužíc po jeho vlastní povaze (عiऽ vov̂v

10 Vzájemnou a nepřetržitou přeměnu jednoduchých těles označuje Aristotelés za „nápodobu“ (něco odvozeného od) prvního kruhového pohybu (337a3-7; srv. česká metafora „koloběhu“ - v Aristotelově textu je ovšem motiv nápodoby figurou kauzální a zároveň hodnotové hierarchie). Vznik a zánik živých bytostí kolem nás jsou vázány na pohyb Slunce po ekliptice (336a32). Oba motivy jsou shrnuty na řádcích 336b2-5: „Přríčinou nepřetržitosti je tudíž místní pohyb vesmírného celku, ale příčinou přichýlení a odchýlení je tu šikmý sklon, nebot' pro něj se stává, že onen pohyb probíhá někdy ve větší vzdálenosti, jindy blíže." Šikmý sklon je příčinou ročních

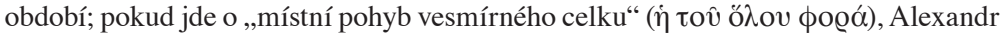
jej chápe jako pohyb sféry stálic, která rotuje nad pohybem Slunce po ekliptice: oba motivy jsou tak uspořádány v souladu se strukturou nebeské sféry. Viz Filoponos, In De gen. et corr., 291,18-21, vyd. G. Vitelli, Berlin 1897. Pro komentář obou typů působení viz Aristotle, De generatione et corruptione, vyd. C. F. J. Williams, Oxford 1982, str. 186-190; Aristote, De la génération et la corruption, vyd. M. Rashed, Paris 2005, str. 173-179. 


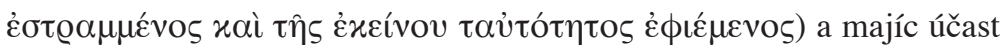

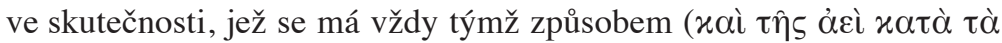

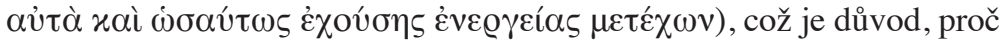
se hýbe neustálým pohybem“ (In De Caelo, 291,34-292,1).

Předností celé Simplikiovy úvahy (viz In De Caelo, 291,5-292,7) je nijak neskrývané přesvědčení, že motiv nebeské touhy, převzatý z Metafyziky XII,8, lze sloučit stejně dobře s platónským idiomem účasti v tom, co je věčně v témž stavu, jako s vlastním textem pojednání $O$ nebi. Stejně jako zásadní redefinice případné nebeské duše, kterou provádí Alexandr a s níž jsme se setkali v první části této studie, také Simplikiova syntéza je filosoficky legitimní, ovšem zdůvodnění jejích předpokladů v Aristotelově textu nenajdeme. Tento text je přitom výrazně jasnější než motiv touhy nebeských sfér, z jehož původního aristotelského znění není zcela jasné ani to, zda je zmíněn jako dále nerozvedená součást nauky, nebo je vhodně využitou metodologickou pomůckou (viz Závěr této studie). Celá citovaná pasáž se ve své afirmativní části drží na fyzikální rovině a je plně slučitelná se vším, co se o prvním tělese dozvídáme v jiných pasážích pojednání $O$ nebi.

\section{O nebi II,6,288a27-b7}

Jiná je situace $\mathrm{v}$ textu $\mathrm{z}$ druhé knihy, $\mathrm{v}$ němž se jedinkrát $\mathrm{v}$ celém spisu

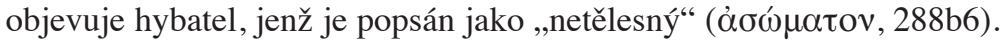
Př́slušná pasáž i celá kapitola, jíž je součástí, se výrazně liší od výše komentované pasáže, v níž jsme sledovali rychlé posuny od fyzikální argumentace ohledně místa, prázdna a času přes platónské motivy a tradiční mínění o bozích až po návrat k pohybu prvního a božského tělesa. Kapitola II,6 nabízí naopak sevřenou argumentaci na jediné a jasně dané téma, jímž je pravidelnost nebeské rotace. Celkový tón kapitoly připomíná Fyziku VII-VIII, mimo jiné i tím, že závěry týkající se konkrétního rysu pohybu nebe jsou provázeny tematizací obecných podmínek, za nichž je daná argumentace platná. Zmíněný konkrétní rys pohybu nebe je přitom tím, co předešlé kapitoly (zejména De caelo, II,2 a II,5) předpokládaly bez výslovného důkazu: totiž to, že kupředu směřující

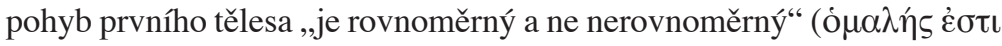

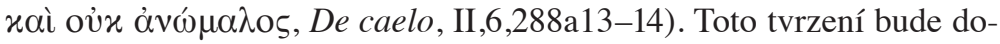
kazováno pro celou nebeskou sféru, přičemž je zjevné, že má být platné pro pohyb vnější sféry stálic i pohyby planetárních sfér. $\mathrm{V}$ tomto bodě se Aristotelés dovolává zkušenosti, jež má podpořit formálněji vedenou 
argumentaci: nerovnoměrné nebeské pohyby by vedly ke změnám vzdálenosti mezi hvězdami, avšak žádné takové změny nepozorujeme (288b10-12). ${ }^{11}$

Hlavní argumentaci kapitoly nicméně na zkušenosti založit nelze, a ke slovu tak znovu přicházejí vlastnosti kruhového pohybu jako pohybu veskrze přirozeného. Po úvodní úvaze o nerovnoměrném pohybu jako pohybu spočívajícím ve zrychlení, dosažení vrcholné rychlosti a zpomalení (288a17-27), proto Aristotelés přistoupí k následující argumentaci složené z pěti úzce provázaných kroků (288a27-b7):

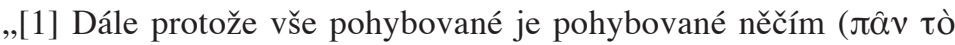

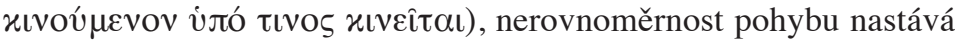
nutně skrze hybatele, nebo skrze to, co se hýbe, nebo skrze obojí; ne-

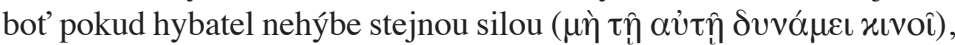
nebo se pohybované mění a nezůstává stejné, nebo se mění oba, nic

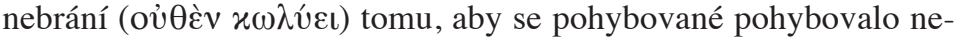
rovnoměrně. [2] Nic z toho však není možné v případě nebe; vždyt' se ukázalo, že [v jeho případě] je pohybované první a jednoduché a nevzniklé a nezničitelné a celkově neměnné; [3] je tak ještě mno-

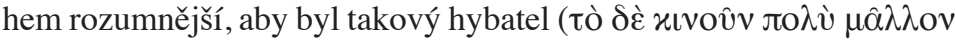

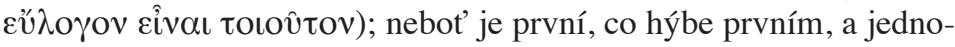
duché jednoduchým a nezničitelné a nevzniklé nezničitelným a ne-

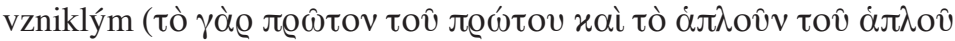

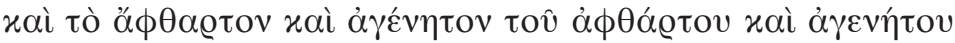

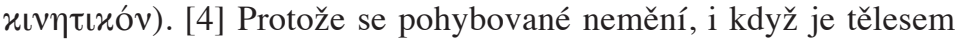
(ở $\mu \varepsilon \tau \alpha \beta \alpha ́ \lambda \lambda \varepsilon \varepsilon \iota \hat{\omega} \mu \alpha$ ǒv), ani hybatel, jenž je netělesný, se měnit

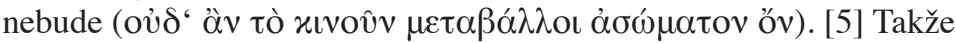
je nemožné, aby byl pohyb nerovnoměrný. "12

Premisa prvního kroku je pro celou argumentaci zjevně klíčová. V tomto případě není pochyb o skutečně spřízněném textu: obdobnou větou

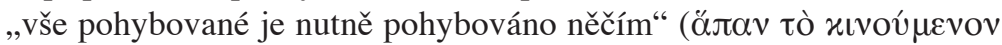

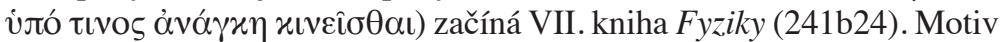

11 Tato úvaha je přirozeně jen podpůrná, nebot' rovnoměrné trvalé a velmi postupné zrychlování či zpomalování nebeského pohybu by mohlo uniknout i pozorování zaznamenávanému po řadu generací. Jak je zřejmé z následujících řádků, Aristotelés zde předpokládá, že naše zkušenost pravidelný pohyb nebe nevylučuje a zároveň nás neustále informuje o různě rychlých pohybech kolem nás, včetně pozorovatelného úpadku až rozpadu živočichů a jejich částí (viz 288b12-18).

12 Aristotelés, De caelo, II,6,288a27-b7. 
netělesného hybatele přitom naznačuje, že citovaná pasáž předpokládá - v jakési extrémní zkratce - celý argumentační postup až do konce VIII. knihy Fyziky. Zvláštností naší pasáže je však úzce vymezený cíl, k němuž zavedení netělesného čili podstatně nehybného hybatele slouží, totiž důkaz rovnoměrnosti nebeské rotace. $V$ tomto ohledu jde o argument, jenž nemá ve Fyzice přímou paralelu. Analýza rovnoměrného a nerovnoměrného pohybu ve Fyzice $\mathrm{V}, 4$ zůstává zcela v kontextu sublunárního světa a Fyzika VIII,9,265b10-11 pouze tvrdí, že jedině kruhový pohyb může být rovnoměrný.

Premisa týkající se hybatele každého pohybu je přitom zavedena zcela obecně a druhý krok citované úvahy je prostě jen připomenutím dokonalosti rotujícího prvního tělesa. Krok (3) je pak s krokem (2) propojen pomocí částic men - de, a sám tedy neupřesňuje povahu kauzálního spojení hybatele a nebeského kruhového pohybu. O této povaze se z celé úvahy nakonec nic konkrétního nedozvíme, nebot' Aristotelés zůstává na rovině podobnosti mezi prríčinou a tím, na co působí: řada týchž predikátů slouží zcela výslovně k popisu obojího. Co je přitom pozoruhodné, je směr vyvozování, které tento popis rámuje: dokona-

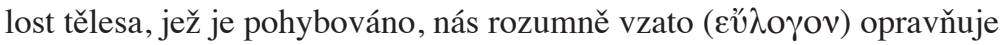
k závěru, že takovou dokonalostí se ,ještě mnohem spíše“ vyznačuje hybatel. Krok (4) pak nabízí analogicky vyvozený závěr, nyní formulovaný stručněji s ohledem na neměnnost, která náleží pohybovanému i hybateli. Za povšimnutí přitom stojí obezřetnost, s níž Aristotelés

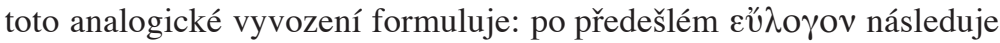
potenciální optativ s modální částí ó $v$, jenž vede Simplikia k poukazu na to, že Aristotelés se v naší pasáži vyjádřil hned dvakrát „opatrně“ ( $\alpha \sigma \phi \alpha \lambda \omega \varsigma):$ nejprve když použil výraz „nic nebrání“ a stejně tak když

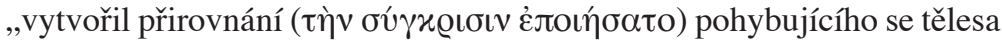
k tomu, co je nehybné a netělesné“ (In De caelo, 426,23-24 a 28-29). Výsledkem je úzce zaostřená, formálně jasná úvaha, v níž hraje přesun vlastností na základě podobnosti klíčovou roli: plyne-li nepravidelnost z pohybovaného, nebo z hybatele, nebo z obojího, přičemž již víme, že pohybované je něčím dokonalým, pak zbývá promítnout podobnou dokonalost do hybatele, jehož netělesnost tedy v textu nehraje žádnou samostatnou úlohu. Ani v závěru úvahy - krok (5) - se Aristotelés k její přesné kauzální roli nevrací.

$\mathrm{Z}$ takto rozebraného argumentačního postupu plyne, že rovnoměrnost je v celé úvaze předpokládána spíše než dokazována (odtud též podpůrný apel na zkušenost). $\mathrm{K}$ čemu je tedy třeba zavádět pouze zde obecnou, avšak velmi úzce užitou premisu hybatele? Nejjednodušší, byt' 
filosoficky nepříliš uspokojivá odpověd’ plyne z postavení šesté kapitoly v celku druhé knihy. Rovnoměrnost nebeské rotace je poslední vlastností prvního tělesa, které se Aristotelés věnuje předtím, než obrátí svou pozornost ke stálicím a planetám. Rovnoměrnost přitom není prostým korelátem dokonalosti prvního tělesa: na rozdíl od dosud pojednávaných vlastností ji totiž nelze odvodit ani z povahy kruhového pohybu, jenž není rovnoměrný nutně (viz znovu Phys., VIII,9,265b10-11), ani z oživenosti prvního tělesa, jež sama o sobě záruku takového pohybu neskýtá. ${ }^{13}$ Rovnoměrnost nebeské rotace je tedy tematicky samostatná a do II. knihy musí být doplněna, zároveň se však zdá, že v její prospěch neexistuje žádný argument, jenž by nakonec nespoléhal na rozumně předpokládanou dokonalost prvního tělesa. Ani v rámci celého spisu nečekané a velmi letmé doplnění netělesného hybatele na této situaci nic nemění. Viděli jsme, že sám hybatel je zde kromě své netělesnosti obdařen vlastnostmi argumentačně přenesenými z toho, čím má pohybovat. Ve srovnání s výkladem nehybného hybatele ve Fyzice VIII stejně jako Metafyzice XII je takový postup zvláštní a zcela jedinečný.

Celá pasáž proto nenabízí slibnou cestu k propojení geometrie a fyziky prvního tělesa s netělesnou, vskutku metafyzickou příčinou. ${ }^{14}$ Výklady usilující o takové propojení postupují způsobem, jenž připomíná Alexandra a jeho redefinici nebeské duše jako přirozenosti prvního tělesa. ${ }^{15}$ Má vlastní interpretace je bližší čtení kladoucímu větší důraz na samu přirozenost prvního tělesa, která je jako jeho esence definována nezávisle na jeho látce. James Hankinson tak v souvislosti s naší pasáží navrhuje, že ,je přinejmenším možné, že ,hybatelem“ je zde vlastní přirozenost či esence (internal nature or essence) pohybujícího se tělesa,

13 Na okraj dodejme, že směr kosmické rotace je v předešlé a krátké kapitole II,5 pojednán ne zcela uspokojivě, ovšem s odvoláním na oživenost prvního tělesa. Svým výkladem pohybu vpřed jako lepšího než jeho protiva tak De caelo, II,5 doplňuje výklad o horní a spodní, a také pravé a levé části nebe z De caelo, II,2. K oběma kapitolám viz O. Goldin, Cosmic Orientation in Aristotle's De caelo, in: Proceedings of the Boston Area Colloquium in Ancient Philosophy, 26, 2011, str. 91-117.

14 Pro obdobný závěr srv. J. Bogen - J. E. McGuire, Aristotle’s Great Clock: Necessity, Possibility and the Motion of the Cosmos in De caelo 1.12, in: Philosophy Research Archives, 12, 1986-1987, str. 423.

15 Ztotožnit nehybného hybatele s vnější nebeskou sférou a současně její duší se snaží A. Kosman, Aristotle's Prime Mover, in: M. L. Gill - J. G. Lennox (vyd.), Self-Motion from Aristotle to Newton (=Self-Motion), Princeton 1994, str. 135-153; ke kritice této snahy viz L. Judson, Heavenly Motion and the Unmoved Mover, tamt., str. $155-171$. 
díky níž se hýbe“. ${ }^{16}$ Takové čtení - opřené o rozlišení mezi pohybem a něčím v pohybu - je jistě věrné Aristotelově opatrnosti. Jeho předností je i to, že zachovává odlišnost citovaného textu od stylu tematizace nehybného hybatele v Metafyzice XII, zároveň však připomíná styčné body s postupem Fyziky. V ní Aristotelés tvrdí, že netělesný a bezrozměrný nehybný hybatel se s nebeskou sférou nehýbe ani akcidentálně (Phys. VIII,6,259b20-28), zároveň jej však hypoteticky umist'uje na její vnější povrch či přesněji obvod, v němž je rotace kosmu nejrychlejší (Phys.

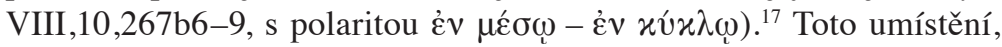
shrnuté výrazem „tam“ ('̇xદî), je ovšem metaforické natolik, nakolik nic kladeného do obvodu kosmu nemůže být přísně vzato v místě: nejen proto, že obvod vyznačující nejrychlejší kosmickou rotaci je geometrický útvar, ale i proto, že svět není zvnějšku obklopen dalším tělesem. Což zároveň znamená, že neustálý pohyb trojrozměrné a tělesné nebeské sféry nevylučuje závěr, že svět jako celek se nehýbe, nebot' nemá místo, v němž by se pohyboval. Celistvá a jedinečná prrirozenost celku světa, završená geometricky prvním tvarem, je proto sama pojmově možným kandidátem na čistě fyzikálně chápanou roli nehybného hybatele. Aristotelés takový závěr nečiní, můžeme jej však vyvodit z výkladů místa a pohybu, k nimž lze jako podpůrný argument přičíst ztotožnění nebeské duše s přirozeností prvního tělesa, s nímž jsme se setkali u Alexandra z Afrodisiady i jeho moderních pokračovatelů (viz první část této studie).

Cílem této odbočky k Fyzice a nezvyklému pohledu na její možnou blízkost pojednání $O$ nebi není nabídnout novou interpretaci vztahu nehybného hybatele a kosmu, ale poukázat na rozmanitost, kterou v různých Aristotelových textech nacházíme. Tato rozmanitost souvisí s nemožností přímo ověřit tu či onu hypotézu týkající se zkušenostně nedostupné nebeské sféry a Závěr této studie se pokusí shrnout filosofické implikace této nedostupnosti. Nejprve nám však zbývá třetí a poslední pasáž, z níž někteří čtenáři vyvozují silnější systematický vztah mezi spisem $O$ nebi a kladením prvního nehybného hybatele v jiných spisech, zejména pak v Metafyzice XII.

16 R. J. Hankinson, Natural, Unnatural, and Preternatural Motions: Contrariety and the Argument for the Elements in De caelo 1.2-4, in: A. C. Bowen a C. Wildberg (vyd.), New Perspectives on Aristotle's De caelo, Leiden 2009, str. 94, pozn. 30.

17 Formální obdoba řady úvah o pohybu ve Fyzice a spisu $O$ nebi přitom nijak nebrání tomu, aby první z těchto textů neprováděl vyvození opačným směrem než De caelo, II,6: v tomto textu jsme sledovali přenos vlastností z pohybovaného tělesa na nehybného hybatele, zatímco Phys. VIII,6,259b22-28, argumentuje z hybatele na pohybované. 


\section{O nebi II,12,292a14-b25}

Zatímco argumentace týkající se rovnoměrnosti nebeské rotace nám přirozeně připomněla některé pasáže $F y z i k y$, naše poslední pasáž připomíná svým tématem, jímž je různost pohybů planetárních sfér, Metafyziku XII,8. Případná blízkost obou textů je posílena tím, že tato pasáž zmiňu-

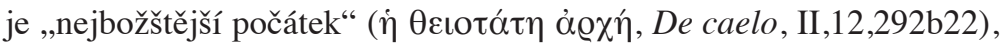
jenž některým čtenářủm potvrzuje názor, že sama nebeská sféra nemůže být prvním a nejvyšším principem..$^{18}$ Bližší pohled na kontext uvedeného výrazu však znovu ukazuje, že sám Aristotelés se takto jasnému vyjádření vyhýbá. Jeho tématem není totiž sám tento počátek, nýbrž způsob, jímž jej dosahují různé pohyby, které jsme schopni v nebeské sféře pozorovat.

Oproti oběma předešlým pasážím jde tedy o výrazný tematický posun, souvisejí s již zmíněným ukončením základní rozpravy o prvním tělese v kapitole II,6. Prvních šest kapitol druhé knihy tak má neustále na zřeteli celkovou jednotu látkového kosmu. Počínaje kapitolou II,7 začíná zkoumání nového a neobyčejně složitého tématu, jež plyne ze zjevné mnohosti pohybů - a tedy pohybujících se těles - v nebeské sféře. Sama existence nebeských těles je přitom záhadou. Kapitola II,7 již vychází z předpokladu látkové jednoty celého nebe včetně různých sfér, v nichž se nebeská tělesa nacházejí: nejrozumnější je říci, že „každá z hvězd je složena z tělesa, v němž má svůj pohyb“ (De caelo, II,7,289a14-15). Je-li ovšem látka celého nebe včetně hvězd a jejich sfér táž a její pohyb je přísně kruhový, co je důvodem mnohosti, kterou na nebi pozorujeme? Odpověd’ na tuto otázku přesahuje meze rozumné úvahy a sám Aristotelés prostě vychází z mnohosti nebeských těles jako dané skutečnosti. Kapitoly 8-9 tak vycházejí z látkové jednoty hvězd a jejich sfér, přičemž vyvracejí další chybná mínění o nebeských tělesech, včetně domnělé analogie mezi pohybem hvězd a živočichů (točí se nebeské sféry, tělesa v nich jsou nehybná, viz De caelo, II,8,290a24-b11). Naproti tomu kapitola 10 se zabývá pořadím čili uspořádáním hvězd na obloze. Po zdůvodnění kulovitého tvaru nebeských těles v kapitole 11 převezme tento problém i 12. kapitola, jejíž zmínka „nejbožštějšího počátku“ nás již př́mo zajímá. ${ }^{19}$

18 Viz stručně a jasně H. Cherniss, Aristotle's Criticism, str. 587.

19 Krátká kapitola II,11 navazuje na kapitolu II,8 a její odmítnutí analogie mezi pohybem živočichů a hvězd. Hvězdy jsou zvláštní případ: stejně jako svět mají vznešený kulovitý tvar bez orgánů živočišného pohybu, postrádají však samostatný 
Kontextem této zmínky je následující problém: pohybů sfér vyjádřených viditelnými pohyby Slunce a Měsíce je zjevně méně než pohybů spjatých se vzdálenějšími planetami (viz 291b28-292a3). Tento pozorovatelný fakt narušuje teoreticky rozumnější nárůst složitosti ve směru od jednoho pohybu sféry stálic přes pohyby sfér jednotlivých planet,které by měly být tím složitější, čím více se vzdalují od sféry stálic. Aristotelovým úkolem je tedy vypořádat se s touto zdánlivou nahodilostí. Odtud návrh postupu, jenž vychází z oživenosti prvního tělesa, kterou individualizuje do obrazu jednotlivých planet jako živých bytostí, smě-

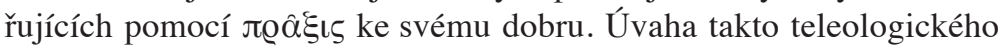
typu, provázená personifikací planet, je v rámci spisu $O$ nebi výjimečná a zdůvodněná nedostatkem empirických poznatků, které má zastoupit (viz De caelo, II,12,292a14-18). Jejím východiskem je rozumné přesvědčení, že nebeská tělesa nejsou jen nějak seřazená neživá tělesa: „Je naopak třeba [o nich] uvažovat, jako by měla účast na činnosti a životě

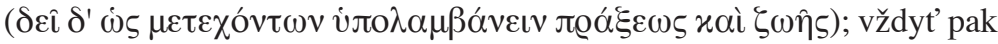

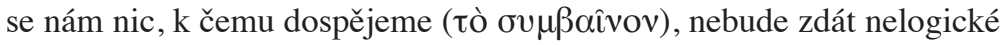

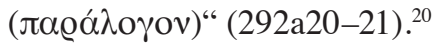

$\mathrm{K}$ čemu dospějeme, vyplyne postupně z úvahy o záměrných činnostech a cíli, jehož mají dosáhnout. Podobně jako v kapitole II,2 máme co činit s myšlenkovým experimentem, jenž není vědeckým odhalením pravé povahy kosmu, ale názornou aplikací premis, které jsou pro daný

rotační (i jakýkoli jiný) pohyb; rovněž v Metafyzice XII,8 konají pohyb nebeské sféry, nikoli stálice či planety.

20 Již překlad první věty tohoto souvětí je věcí interpretace. Místo „uvažovat, jako by měla účast na činnosti a životě“ lze překládat „vzít v úvahu, že mají účast na činnosti a životě“. K dvojznačnosti celého souvětí viz velmi podrobně A. C. Bowen, Simplicius on the Planets and Their Motions: In Defense of a Heresy, Leiden 2013, str. 227-229. K překladu ஸ் výrazem, ,jako by“ viz též Aristotle, On the Heavens I and II, vyd. S. Leggatt, Warminster 1995, str. 248 n. (s dalšími odkazy). Tento překlad volím též s ohledem na $\pi \varrho \hat{\alpha} \xi ı \varsigma$, kterou Aristotelés jinde s nebeskými tělesy nespojuje a která ohlašuje následující analogii s lidskými činnostmi. Pro obdobný názor, že Aristotelés zde nepředkládá kosmologickou nauku, ale hledá způsob, jímž dát různosti planetárních pohybů alespoň nějaký smysl, viz Ch. Rapp, Aristotle and the Cosmic Game of Dice. A Conundrum in De Caelo II.12, in: Rhizomata, 2, 2014, str. 165-167. K ústřední analogii planetárních pohybů a lidského cvičení srv. též R. W. Sharples, Responsibility and the Possibility of More than One Course of Action: A Note on Aristotle De caelo II, 12, in: Bulletin of the Institute of Classical Studies, 23, 1976, str. 69-72. Pro výklad celé kapitoly s důrazem na vztah k aristotelské dialektice viz A. Falcon - M. Leunissen, The Scientific Role of Eulogos in Aristotle's Cael ii 12, in: D. Ebrey (vyd.), Theory and Practice in Aristotle's Natural Science, Cambridge 2015, str. 217-240. 
účel rozumně přijatelné. Hlavní premisa je přitom jasná: zatímco „nej-

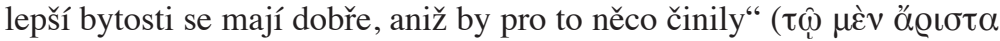

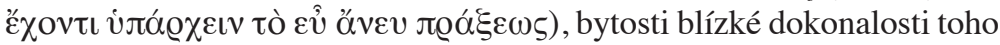
musí činit málo, vlastně jen jednu věc, a bytosti dokonalosti vzdálené musejí vykonávat činností více (292a22-24). Obdobně je tomu s lidským tělem: jedno je v dobrém stavu bez cvičení, druhé potřebuje pouze krátké procházky a další běh a zápas a jiné činnosti (292a24-26). ${ }^{21}$ Tak zní krátký úvod celé analogie, jejîž rozvitá podoba srovnává hvězdy na straně jedné s živočichy i rostlinami na straně druhé. Zvláštní postavení mají v této druhé skupině lidé, kteří vykonávají nejvíce činností, a na opačném konci rostliny, jimž patři snad jen jediná činnost a jejich postavení odpovídá v celém schématu nehybné Zemi. V př́ípadě všech bytostí včetně člověka - a zjevně i hvězd a planet - přitom existuje jedno skutečné dobro a stav dané bytosti bude nejlepší, pokud svého dobra dosáhne, v jiném případě pak vždy tím lepší, čím více se mu přiblíží (viz celkově 292b1-19, s opakovaným příkladem tělesného zdraví).

Rozšîrení úvahy o mnoha pohybech a dosahování vlastního dobra až do nebeské sféry se tedy opírá o kladení vlastního dobra, o něž každá živá bytost ve své činnosti usiluje. A zároveň o představu, že takové dobro není tak silně vlastní tomu či onomu druhu živé bytosti, že by nebylo možné vytvořit na jedné straně sublunární hierarchii, jejímž vrcholem je bytost nadaná nejvíce možnými činnostmi, a na druhé straně nebeskou hierarchii, jež vrcholí jedním pohybem sféry stálic. Situaci člověka a bytostí kolem něj text nijak nerozvíjí a místo toho se soustředí na závěr, jenž však aplikuje výchozí premisu víceméně popisným způsobem:

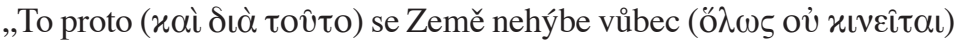

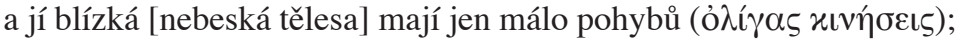

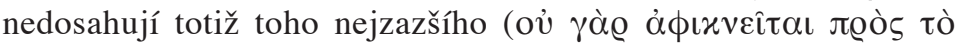

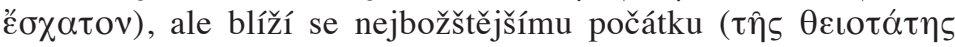

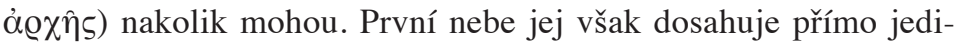

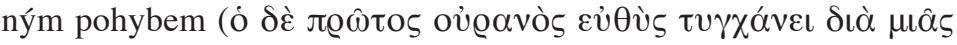

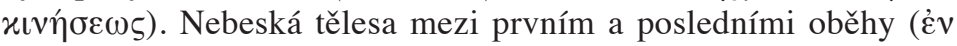

21 Někteří lidé, dodává ještě Aristotelés, nedospějí přes sebevětší úsilí ke kýženému dobru, ale k něčemu jinému. Tento dodatek je stěží součástí analogie s nebeskými tělesy. Ostatně už sám předpoklad, že nebeská tělesa nejsou přirozeně vždy ve svém nejlepším stavu, jasně dokládá, že jde o pomocnou úvahu. Na poznámku o marnosti některé snahy navazuje krátká úvaha o těžkosti opakovaného úspěchu v mnoha věcech, což ilustruje příklad házení kostkou. K této odbočce i samotnému př́ikladu viz Ch. Rapp, Aristotle and the Cosmic Game of Dice. 


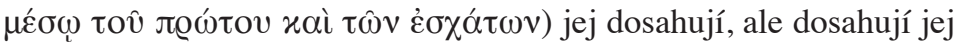

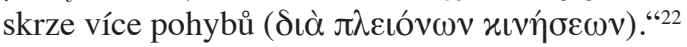

Tolik závěr, jenž popisuje posloupnost sfér z hlediska počtu pohybů, které lze promítnout do jimi unášených těles: jediný pohyb náleží vzdálené sféré stálic, malý počet pohybů planetám blízkým Zemi, větší počet pohybů planetám mezi obojím. Na popisné rovině nelze jistě nic namítat, ovšem skutečného vysvětlení, proč je tomu právě takto, se nám nedostalo. Podle premisy celé úvahy je např́klad Měsíc v lepším stavu než svými sférami složitěji unášený Mars, a to bez ohledu na jejich místo v celkovém uspořádání nebe. Důvod této situace je nám ale stále neznámý - víme jen, že je dobré uvažovat, jako by tato situace nějaký důvod měla, byt' naše poznávací schopnosti k jeho odhalení nestačí. Následné tvrzení, že různé pohyby nebeských těles jsou snad způsobem, jímž

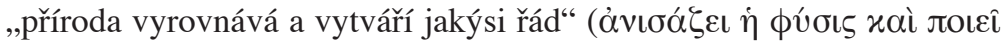

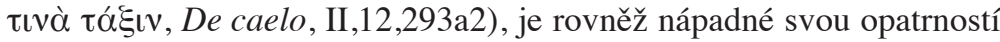
včetně absence jakéhokoli náznaku, čemu právě toto a ne jiné uspořádání nebe prospívá. Dokonce ani možnou prospěšnost sluneční dráhy životu na Zemi zde Aristotelés nezmiňuje. ${ }^{23}$

Vzhledem ke všem uvedeným nejasnostem je přirozené, že pozornost řady interpretů se nakonec soustředí na otázku, zda citovaný závěr prostě jen potvrzuje, že planetární pohyby nedosahují jednoduchosti pohybu sféry stálic, nebo mîrí k netělesnému cíli všech nebeských pohybů, jímž by byl první nehybný hybatel označený za „nejbožššejší počátek“. Sám text je v tomto ohledu obtížně rozhodnutelný a je třeba mít na mysli, že tento počátek se zdá být totožný s tím, co předešlá věta označuje za tò

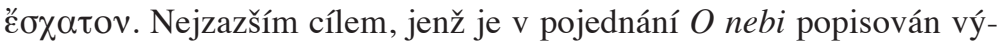

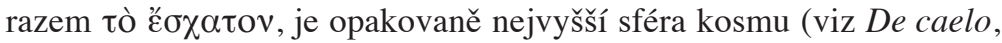
II,13, 296a12; II, 14, 296b14 a b29; srv. I, 3, 270b15) a není žádný nutný důvod, proč by tomu mělo být v naší pasáži jinak. Nerozhodný je oproti

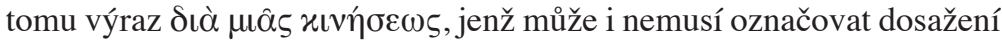
cíle vnějšího danému pohybu: je-li vlastním dobrem prvního tělesa jeho dokonalý kruhový pohyb, právě tímto pohybem toto těleso svého dobra dosahuje. Toto čtení je jistě v souladu s pasáží II,2,285a27-31, v níž je

22 Aristotelés, De caelo, II,12,292b17-25.

23 Viz pozn. 20 výše. Stranou ponechávám fakt, že různost nebeských pohybů je obtížně pochopitelná vzhledem k identické látce celého prvního tělesa, jež - jak víme - žádné kondiční cvičení nepotřebuje (srv. De caelo, II,1,284a15). Tato látková identita je patrně důvodem, proč jsou i jednotlivá nebeská tělesa, unášená sférami,

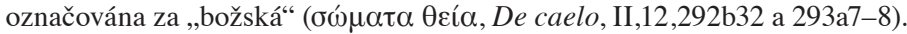




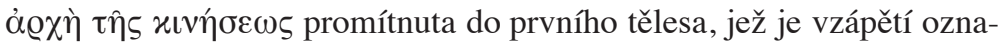
čeno za „božské“ (De caelo, II,3,286a8-12) (viz první část této studie).

Na druhé straně však nelze popř́it podobnost citované pasáže s jinými texty počínaje Fyzikou VIII,6,260a17-19, v níž udílí nehybný hybatel tomu, čím hýbe, ,,jediný jednoduchý pohyb“. Důležitá mez této podobnosti však plyne z toho, že toto kauzální schéma nelze přímo promítnout do naší pasáže $O$ nebi, nebot' oba texty se pohybují na různé argumentační rovině. Z hlediska VIII. knihy Fyziky by bylo udílení jednoho pohybu nehybným hybatelem naprosto stejné u každé jednotlivé sféry bez ohledu na výsledný pohyb, jež unáší viditelnou planetu. Na nezjevné rovině nebeských pohybů jako rotačních pohybů sfér není v prvním tělese znovu nic jiného než jednoduchý pohyb bezprostředně dosahující svého plného uskutečnění. Jakmile chceme zdůvodnit jevovou různost těchto výsledných pohybů, ocitáme se naopak v kontextu, jenž přesahuje formální výklad vztahu hybatele a pohybovaného. Měli bychom tedy hledat slibnější obdobu v Metafyzice XII, která na rozdíl od Fyziky VIII přesahuje horizont úžeji pojaté vědy o prrírodě a nabízí přehled různých druhů podstat včetně nehybného, nelátkového božstva definovaného výhradně myšlením?

Kladnou odpověd’ na tuto otázku předpokládá řada syntetických výkladů, antických i moderních, jejichž přirozeně se nabízejícím východiskem je Metafyzika XII,7, v níž je nehybný hybatel věčného pohybu nebe popsán jako žádané dobro a obdařen jedinou vlastní činností, jíž je myšle-

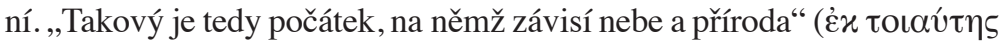

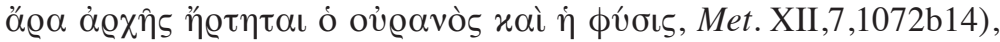
tvrdí Aristotelés, a jistě nám tak připomíná „nejbožššejší počátek“ z po-

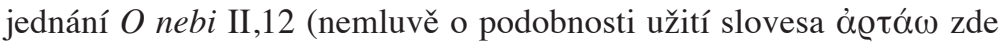
a slovesa $\dot{\varepsilon} \xi \alpha \varrho \tau \alpha ́ \omega$ ve výše analyzované kapitole I,9). Otázkou ovšem zůstává, jak dalece nás má vést lexikální podobnost a zda na ni máme klást větší důraz než například na tvrzení z řádků Met. XII,7,1072b5-6, podle něhož ,je-li něco pohybováno, může se chovat také jinak“, i kdyby ,jen co do místa, i když ne co do podstaty“. Právě o vyloučení této možnosti se stará velká část argumentace, díky níž spis $O$ nebi předkládá čistě fyzikální, byt' geometricky založenou, koncepci prvního tělesa. Má-li Metafyzika XII,7 naznačit, že tato koncepce je nedostatečná a pouze nehybný první hybatel zaručí pravou neměnnost nebeského pohybu, nejde o doplnění spisu $O$ nebi o motiv, jenž prostě zůstal nevysloven, ale o zásadní posun k odlišnému pojetí nebeské látky. Námitkou vůči tomuto čtení pak může být hypotéza, že Aristotelés zde implicitně navazuje na motiv „netělesného hybatele“ z výše probírané kapitoly II,6, takže 
„chováním jinak“ nemá na mysli nic jiného než hrozbu nepravidelnosti místního pohybu, jemuž chybí vnější netělesná záruka.

Předešlý odstavec je pouze nepatrným vzorkem jistě důležitých diskusí, v nichž lze pokračovat s rostoucí mírou podrobnosti i širirkou záběru libovolně dlouho. Nerozhodnutelnost celé otázky plyne i z toho, že $\mathrm{Me}$ tafyzika XII, včetně své osmé kapitoly věnované pohybu nebeských sfér, nenabízí žádné odpovědi na řadu otázek ohledně působení prvního hybatele na celkovou nebeskou rotaci i pohyby jednotlivých sfér. Protože výklad Metafyziky není předmětem této studie, stačí snad zmínit dva typické problémy, které z absence podrobnějšího vysvětlení plynou. Problém první: kapitola XII,8 hovoří o vztahu prvního hybatele k celku nebeské rotace (1073a23-25), nedodává však vůbec nic o tom, jak se k němu vztahují pohyby jednotlivých sfér uvnitř nebe. Řečeno jednoduše, i přes líčení prvního hybatele jako účelové př́ičiny nakonec Metafyzika XII uhýbá před sjednocením nebeských pohybů jejich orientací ke společnému cíli čili dobru, tedy jednomu vskutku prvnímu hybateli. Dozvídáme se pouze, že vedle hybatele ,jednoduchého místního pohybu celku“ musí existovat též další hybatelé věčných pohybů planet (1073a26-b1). Jejich definice se přitom nemůže formálně lišit od hybatele celkové kosmické rotace a nezdá se, že by zde vyvstávala možnost jakékoli skutečné hierarchie. ${ }^{24}$ Pokud bychom tak chtěli promítnout prvního hybatele do pojednání $O$ nebi, nezískali bychom lepší vysvětlení nebeských pohybů, než jaké nabízí myšlenkový experiment v kapitole II,12.

Problém druhý: z Aristotelova uvažování jako by však zároveň plynulo, že nelátkový hybatel může být pouze jeden. Příslušný text stojí za poslední souvislejší citaci:

„Je zřejmé, že je jedno nebe. Nebot' kdyby jich bylo více, jako je více lidí, byl by počátek pro každé co do druhu jeden, co do počtu by jich však bylo mnoho. Avšak všechno, čeho je na počet mnoho,

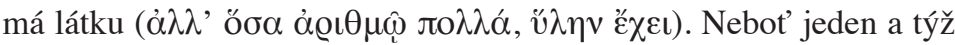
pojem, například ,člověk“, náleží mnohým, Sókratés však je jeden.

24 K pasáži a otázkám, které navozuje, viz I. Bodnár, Cases of Celestial Teleology in Metaphysics $\mathbf{\Lambda}$, in: Ch. Horn (vyd.), Aristotle's Metaphysics Lambda - New Essays, Berlin 2016, str. 260 n. Srv. též: Aristotelés, Met. XII,8,1074a17-31, se závěrečným shrnutím výkladu nebeských sfér a jejich pohybů: ,Ježto se nemůže postupovat bez konce, musí cílem každého pohybu být nějaké božské těleso, pohybující se na nebi.“ 


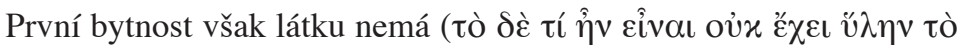

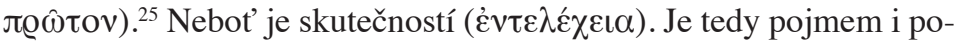
čtem první nehybný hybatel jeden. Proto je jenom jedno také to, co je stále a nepřetržitě pohybováno. Je tedy jenom jedno nebe.“26

Jak na pozadí tohoto textu rozlišit pohyby sfér a připsat jim jejich vlastní a navzájem odlišné nelátkové hybatele? Možné východisko bylo spatřováno ve zmíněné pasáži o hybatelích sfér (Met. XII,8,1073a26-b1), která nevylučuje výslovně, že by se na rozdíl od prvního hybatele tito hybatelé hýbali akcidentálně a neměli tedy stejný status jako hybatel „,první“. 27 Akcidentální pohyb je navíc rysem, jenž je vlastní sublunárním duším. Tato možná blízkost, kterou sám Aristotelés nezmiňuje, posiluje sklon řady čtenářů proměnit nehybné hybatele nebeských sfér v jejich duše, či přesněji rozum, jenž touží po př́islušném nehybném hybateli a slouží jako svého druhu převodovka mezi tímto hybatelem a pohybem příslušné sféry. K čemuž je zdravé dodat, že motiv rozumu a rozumové touhy po dobru, jež působí jako hybný činitel, se v celém výkladu objevuje ve velice obecné podobě, jejíž konkretizaci na případ nebeských pohybů Aristotelés nepředvádí (viz Met. XII,7,1072a26-30; 1072b2-5). ${ }^{28}$

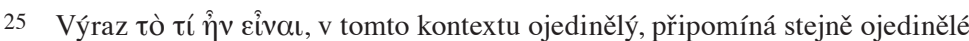
užití v De caelo, I,9,278a2-4; v obou prrípadech jde zřejmě o připomenutí, že látka není součástí definice podstaty.

26 Aristotelés, Met. XII,8,1074a31-38.

27 Viz I. Bodnár, Cases of Celestial Teleology, str. 248 n.

28 Nedávným zastáncem předpokladu duší sfér, mimo jiné na základě propojení s relevantními pasážemi z De an. a Eth. Nic., je A. Laks, Metaphysics $\Lambda 7$, in: M. Frede - D. Charles (vyd.), Aristotle's Metaphysics Lambda, Oxford 2000, str. 221: „The heaven should be, or should have, if not a sensitive soul, then at least an intellect which would be a desiderative intellect.“ K otázce „,kosmické touhy“ (zejména na základě De caelo, II,12) srv. též Ch. H. Kahn, The Place of the Prime Mover in Aristotle's Teleology, in: A. Gotthelf, Aristotle on Nature and Living Things, Pittsburgh - Bristol 1985, str. 192-193. K duším sfér viz též S. Broadie, Heavenly Bodies and First Causes, in: G. Anagnostopoulos (vyd.), A Companion to Aristotle, Oxford 2009, str. 230-241, jejíž otázky místy připomínají Theofrastovy pochyby zmíněné v první částí této studie. Srv. str. 240: „Why does the sphere's love of its unmoved mover give rise to rotation? Are there two sphere-activities, rotation and loving the unmoved mover, or could these be different aspects of a single activity?" V této souvislosti je též třeba připomenout, že at' už sféry mají či nemají mít duši či rozum, Aristotelés zavádí v kapitolách XII,7-8, nehybného hybatele i hybatele jednotlivých sfér bez ohledu na tento motiv: stejně jako ve Fyzice jde prostě o důsledek premisy, podle níž má každý - i věčný - pohyb svého kauzálně primárního hybatele. 
Už z těchto dvou obtíží vysvítá, jak složité je přesně stanovit, co bychom získali tím, že bychom do pojednání O nebi promítli výroky o prvním hybateli a dalších nelátkových hybatelích (natolik mohou v čistě nelátkové podobě existovat), které se objevují v Metafyzice XII. Tato obtíž však není čistě negativním závěrem, ale má svůj vlastní filosofický rozměr, jenž souvisí se skutečně odlišným, spíše než komplementárním zaměřením obou textů. Jejich metodologická různost, přirozeně daná růzností tematickou, totiž nevylučuje podobnou, jen různě aplikovanou motivaci, jež vede k vypracování pojmu prvního tělesa na straně jedné a pojmu prvního nehybného hybatele na straně druhé. Otázce Aristotelovy filosofické motivace je proto věnován stručný Závěr společný oběma částem této studie.

\section{Závěr}

Obě části této studie se soustředily na pasáže pojednání $O$ nebi, které se významně liší od navázání kosmické rotace a dalších pohybů na prvního nehybného hybatele ve Fyzice VIII a zejména Metafyzice XII. Pro uznání skutečné odlišnosti těchto textů je ale třeba nezapomínat, co mají společného na základní metodologické úrovni: at' už vycházejí ze zkoumání pohybu nebo druhů podstaty, vypořádávají se s nutností překračovat uznané meze zkušenosti, a to za předpokladu, že tyto meze nejsou mezemi filosofického zkoumání. Filosofie se v Aristotelově pojetí nemůže vyhnout aporiím, které vyvstávají nejen na poli metafyziky, ale též na poli kosmologie. Na rozdíl od aporií výslovně pojednávaných v Metafyzice neplynou aporie spisu $O$ nebi z různých stránek zkoumání podstaty, ale mnohem přímočařeji z našeho postavení ve světě a nemožnosti přímo prozkoumat nebe jako fyzikální oblast.

Tato výchozí situace se promítá do sledu výslovně pojmenovaných aporií, které spis $O$ nebi I-II řeší. První dvě aporie lze řešit logickým uvažováním na základě fyzikálních premis: jedná se o hádanku mnoha světů (De caelo, I,7,274a24-26) a obtíže plynoucí z protichůdných názorů starších myslitelů na to, zda svět vzniká a zaniká, či nikoli (De caelo, I,10,279b4-8). Další aporii lze řešit logickou úvahou na základě premis biologických: týká se nám známého určení pravé a levé strany otáčející se koule (De caelo, II,2,285a31-b1). Následuje obdobná aporie řešená podobně jako aporie předchozí, včetně zapojení hodnotového soudu: jak víme, že se svět opravdu točí (lepším) směrem dopředu (De caelo, II,5,288a2-12)? Konečně jsou za aporie označeny problémy, které nelze 
skutečně vyřešit, ale můžeme je objasnit pomocí analogie: v kapitole II,12 se „největší aporie“ ( vztahu mezi celkovou rotací nebeské sféry a různými pohyby planet. Co z takto stručného přehledu plyne, je společná základní otázka, které se z různých úhlů týkaly i všechny texty zkoumané v obou částech této studie: otázka jednoty a ucelenosti podstatně pohyblivého světa.

Skrze tuto otázku se fyzikální zkoumání nakonec přece jen setkává s metafyzickým tázáním: představa jednotného a uceleného světa - což je zde relevantní význam slova oủ @avós (viz De caelo, I,9,278b20-21) - je totiž představa světa jako individuální podstaty. Že takto chápe svět i spis $O$ nebi, se potvrzuje na několika místech, včetně tvrzení z kapitoly I,9,278b3-4, že „svět (ov̉@avós) patří mezi jednotliviny a věci složené z látky“. Ve zkratce lze jistě říci, že celé pojednání vychází ne z jistoty, ale z „rozumného“ a postupně upřesňovaného předpokladu, že svět je jedna, nějakým zpo̊sobem sjednocená látková věc, a ještě přesněji jediný přirozený celek zahrnující všechny podstaty složené z formy a látky. ${ }^{29}$ Právě toto zahrnutí je úzce propojeno s pohybem první nebeské sféry, přičemž důraz na samostatnost tohoto pohybu byl hlavním tématem této studie. Žádné pojednání tohoto tématu by však nemělo opominout přiznanou nemožnost empirického ověření vlastností tělesa, jež příslušný pohyb vykonává. Odtud zvláštní nejasnost nikoli ohledně toho, $z d a$ je svět jednou podstatou, ale ohledně toho, jaký druhem podstaty je těleso, na jehož pohybu fyzikální jednota světa závisí - což je otázka více metafyzická než fyzikální.

Důvod takového tvrzení souvisí s rysem, jímž se oủ @avó (ve smyslu nebe i světa) vyznačuje jako jednotlivá složenina formy a látky: je něčím

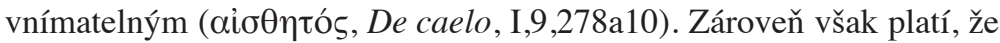
tato vnímatelnost má dvojí různou mez. Nejde jen o to, že principiálně vnímatelné všeobjímající nebe, a tím rovněž svět, nemůžeme jako celek vnímat z žádného místa v něm. Jde zároveň o to, že samo první těleso se sférami, které má obsahovat, nemá žádné vlastnosti, které bychom mohli smyslově vnímat, takže ho „vnímáme“ jen nepřímo, skrze di̊sledek jeho pohybu, jímž jsou viditelné změny polohy nebeských těles. Toto druhé omezení je svou povahou vážnější než evidentní nemožnost spatřit celek světa; má totiž své důsledky pro způsob, jímž se první těleso

29 K motivu světa jako složené podstaty viz M. Matthen - R. J. Hankinson, Aristotle's Universe. Its Form and Matter, in: Synthese, 96, 1993, str. 417-435, a M. Matthen, The Holistic Presuppositions of Aristotle's Cosmology, in: Oxford Studies in Ancient Philosophy, 20, 2001, str. 171-199. Matthen nabízí syntetické čtení, integrující do úvah o světovém celku motiv prvního nehybného hybatele. 
řadí do druhého ze tří druhů podstaty podle Metafyziky XII,1. Rozlišení trojí podstaty na řádcích Met. XII,1,1069a30-b1 vychází z hlavní dicho-

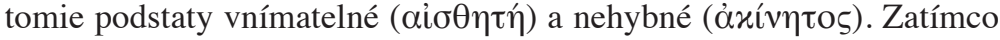
existence podstaty nehybné, jejíž zkoumání náleží jiné vědě než fyzice, není obecně přijímána, na existenci fyzikou zkoumané podstaty vníma-

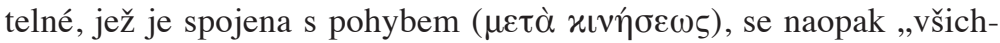

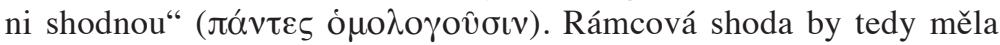
panovat i na dvou druzích této podstaty: podstatě pomíjivé, jako jsou

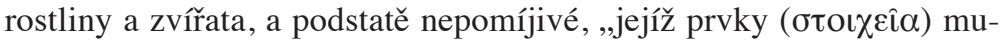

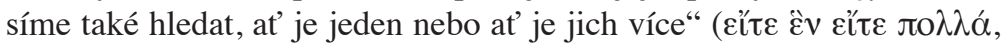
Met. XII,1,1069a32-33). Tento rozvrh nám okamžitě připomene, jak podivným prvkem čili jednoduchých tělesem je těleso první, jež rozšiřuje počet prvků na pět, tedy o jeden více než nacházíme u myslitelů jako Empedoklés či Platón. Toto rozšîrenení je přitom zvláštní nejen historicky, ale především z hlediska právě uvedeného roztřídění podstat. Je-li pravda, že ostatní čtyři jednoduchá tělesa (prvky čili živly) nelze vnímat jinak než skrze odvozenou jevovou podobu ve směsích, jimiž jsou pomíjivé podstaty, nebeské první těleso není vnímatelné ani takto odvozeně, nebot' do žádné směsi nevstupuje (nemá žádnou ze vzájemně protivných vlastností, které míšení umožňují). Jediné, co vnímáme při pohledu tam, kam naše geometricky vedené úvahy o pohybu dosadily první těleso, je sluncem rozzářená denní obloha, nebo temná obloha noční, tvořící pozadí pro svítící hvězdy. Obě situace se uskutečňují v průhledném prostředí, jímž je první těleso (viz De an. II,7,418b11-13), přičemž obtíže s jejich fyzikálním vysvětlením (či přesněji absence vysvětlení záře hvězd) indikují paradox, plynoucí z umístění prvního tělesa mezi vnímatelné podstaty spjaté s pohybem: první těleso je sice v neustálém místním pohybu, ale není jako takové vnímatelné; vnímatelné jsou naopak z něj tvořené hvězdy, které však - na rozdíl od jiných živých podstat - nemají žádný vlastní pohyb (viz De caelo, II,9,291a26-27).

První těleso je však zároveň tím, jež z definice obepíná všechny vnímatelné podstaty. Navzdory uvedenému paradoxu je tak Aristotelés potřebuje do schématu podstat zařadit, má-li jeho nauka patřit $\mathrm{k}$ těm, jež

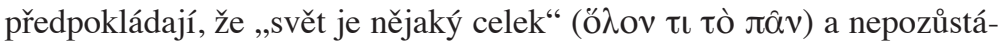
vá jen z jedné věci za druhou (

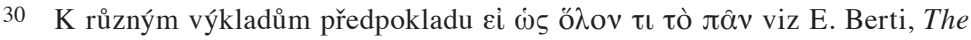
Program of Metaphysics Lambda (chapter 1), in: Ch. Horn (vyd.), Aristotle's Metaphysics Lambda, str. 69-71. Tento předpoklad odpovídá již zmíněnému třetímu významu slova oủ@avós podle De caelo, I,9,278b20-21: tímto slovem označujeme

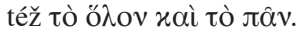


Ani tento předpoklad nelze doložit přímou zkušeností, nebot' je tím, co zkušenost $\mathrm{v}$ nejzazším horizontu uspořádává. Vztah mezi představou jednotného kosmu a nevnímatelným tělesem, které nelze rozpoznat ve smîšených podstatách, je nakonec silnější, než možná sám Aristotelés zamýšlel. Tento vztah lze totiž promítnout i do shrnující formulace z poslední kapitoly Metafyziky XII: „A kdyby nebylo nic vedle smyslových

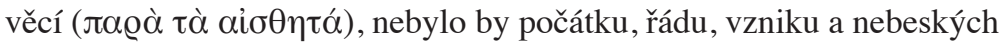

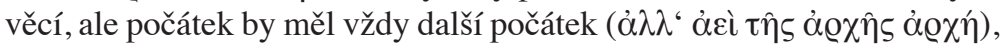
jako to nalézáme u všech fyziků a theologů“ (1075b24-27). První těleso totiž nejenže není vnímatelné, ale neplatí pro něj ani definice látkových věcí jako nositelů protivných určení (1075b21-24). Sesadit první těleso z role prvního počátku, jenž nemá žádnou protivu, lze tedy jen zavedením prvního nehybného hybatele, jemuž však formální argument na rovině fyziky nemůže připsat žádnou vlastní skutečnou činnost. Čirou skutečnost v jiné podobě, než kterou je výkon dokonale kruhového pohybu, může zavést jen nefyzikální, plně metafyzická definice nelátkové a nevnímatelné podstaty jako činnosti na ničem nezávislého myšlení.

Sama Metafyzika XII tak do značné míry potvrzuje, že problém duality počátků nemá metodologicky jednotné řešení: jak uznává závěr pasáže rozlišující trojí podstatu, fyzika a věda o nehybné podstatě „,ne-

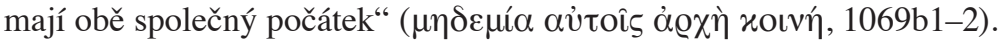
Pro aristotelskou tradici bude i proto jednodušší nauku o prvním tělese přepracovat, nebo zcela odmítnout. V rámci Aristotelova pojetí fyzikálního světa je přesto první těleso nutné, aby se uzavřený kosmos mohl stát „transcendentální ideou“. Tento Kantův výraz, jenž se vztahuje i na ideu světa jako empirického a přece nadsmyslového předmětu, ${ }^{31}$ si lze vypůjčit ke zdůraznění toho, že nejen první nehybný hybatel, ale i pojem prvního tělesa plyne z hledání nepodmíněného počátku podmíněné zkušenosti. $^{32}$

\section{ZUSAMMENFASSUNG}

Aristoteles' De caelo I-II legt die vollkommene Kreisbewegung als eine Art der Bewegung fest, die notwendigerweise der Himmelsphäre angehört, die selber aus einer korrelativ vollkommenen und innerlich

31 I. Kant, Kritika čistého rozumu, přel. J. Loužil, Praha 2001, A 481-482/B 509-510.

32 Tato studie vznikla s podporou GAČR v rámci projektu GA17-05919S. 
beseelten „Ersten Substanz unter den körperlichen Substanzen“ besteht. Letztere, ungeachtet ihrer vollständig materiellen Natur, wird wiederholt beschrieben als etwas Göttliches und örtlich Getrenntes vom sublunaren Bereich von Entstehen und Vernichtung, und kann legitimerweise als der einzige Körper verstanden werden, der sich selbst bewegt in einem vollen, uneingeschränkten Sinne. Es stellt sich daher die Frage, wie es Aristoteles gelingt, diese seine echte kosmologische Innovation mit denjenigen Passagen zu versöhnen (oder eben nicht zu versöhnen), die einen nicht-materiellen Verursacher oder einen unbewegten Beweger einführen, der offensichtlich für die selbe himmlische Bewegung verantwortlich ist, oder, allermindestens, für einige von ihren Eigenschaften. Bezüglich von De caelo selbst haben sich die Interpreten auf drei Passagen konzentriert, die das Vorhandensein eines solchen Bewegers in dieser Abhandlung zu enthalten scheinen (I,9,279a11-b3; II,6,288a27-b7; II,12,292a14-b25). Der erste Teil dieses Beitrags bietet eine eingehende, erneute Untersuchung dieser Passagen und kommt zu dem Schluss, dass keine von denen eindeutig auf einen unbewegten Beweger als die Quelle der himmlischen Bewegung hindeutet. Dieser Schluss macht es allerdings umso wichtiger, nach der Beziehung - im zweiten Teil des Beitrags - zwischen De caelo und insbesondere Metaphysik XII zu fragen, wo solch ein Beweger eine wichtige Rolle in der Erklärung der Anordnung des Universums, einschließlich seiner himmlischen Sphäre, spielt. Anstatt einer entwicklungsmäßigen Erläuterung kommt der Beitrag zu dem Schluss, dass sich Aristoteles nicht darum bemüht hat, ein übergreifendes Schema herauszuarbeiten, dass imstande wäre, das sich selbst bewegende Prinzip der Himmelsphäre (ein Prinzip, für den im Rahmen der Aristotelischen Naturphilosophie plädiert wird) mit der Vorstellung des unbewegten Bewegers zu versöhnen, dessen Aktivität im Denken besteht und dessen Wesen zutiefst metaphysisch ist.

\section{SUMMARY}

Aristotle's De caelo I-II establishes the perfect circular motion as the kind of motion that necessarily belongs to the celestial sphere, which itself consists of a correlatively perfect and internally animate 'first of bodily substances'. The latter, despite its entirely material nature, is repeatedly described as something divine and topically separate from the sublunary realm of generation and destruction, and it can be legitimately understood as the only body that moves itself in a full, non-qualified 
sense. The issue is therefore to find out how Aristotle reconciles (or fails to reconcile) this properly cosmological innovation with the passages where he introduces a non-physical agent or an unmoved mover that is apparently responsible for the same celestial motion or, at the very least, for some of its properties. Concerning the De caelo itself, commentators have focused on three passages which seem to imply the presence of such a mover in this treatise (I,9,279a11-b3; II,6,288a27-b7; II,12,292a14b25). The first part of this article offers a close reexamination of these passages and concludes that none of them points unequivocally towards the unmoved mover as a source of celestial motion. This conclusion, however, makes it even more pressing to ask, as we do in the article's second part, about the relation between the De caelo and, especially, Metaphysics XII, where such a mover plays an important role in explaining the arrangement of the universe including its celestial sphere. Instead of relying on the developmental explanation, the article concludes that Aristotle does not strive to elaborate an overarching scheme that would reconcile a self-moving principle of celestial motion (a principle argued for in Aristotle's natural science) with an unmoved mover whose activity consists in thinking and whose nature is properly metaphysical. 